\title{
Éditorial/Editorial
}

\section{Special Issue Editorial:}

\section{7th In Sickness \& In Health International Research Conference: Technologies, Bodies \& Health Care}

From 7-9 June 2018 we gathered on the Rozelle Campus of the University of Tasmania, in Sydney, Australia to extend the tradition of the In Sickness and In Health Conferences. These conferences were born from like-minded individuals (Helsinki-7) who were interested in creating an international network of critical health scholars and scholarship in relation to power, practice and ethics in health care. At the 7th In Sickness and In Health: Technologies, Bodies and Health Care we came from around the world to engage in critical discussions regarding technology and its interface with the social and material body in health and illness. Nowadays, technologies have permeated and contributed to an ideology of efficiency across the social, critical conversations are needed more than ever. With opportunities for critical discussions becoming increasingly rare and vitally important, I am very pleased to see us continue the conversation with an even wider audience through this special edition of Aporia - The Nursing Journal.

Thank you to all authors who have contributed to this special edition of Aporia - The Nursing Journal. I also extend my gratitude to the Editor-in-Chief of Aporia - The Nursing Journal, Professor Dave Holmes, for the opportunity to continue engaging in critical conversations about the assemblages and relations between technologies, bodies and health. I hope that each and every one of you will find the content of these papers thought provoking and inspiring.

I look forward to continuing our conversations at the 8th conference 10-12 June, 2020: People, Origin and the End of the Universe, Lleida, Spain. https://isihconference.com/isih-2020/

Rochelle Einboden, RN, PhD

Conference Chair

In Sickness \& In Health Conference 